\title{
Effect of Litter on Development and Severity of Foot- Pad Dermatitis and Behavior of Broiler Chickens
}

\section{-Author(s)}

\section{Zikic $D^{\prime}$}

Djukic-Stojcic $\mathrm{M}^{\prime}$

Bjedov $\mathrm{S}^{\prime}$

Peric L'

Stojanovic $S^{\prime}$

Uscebrka G'

University of Novi Sad, Faculty of Agriculture, Dositeja Obradovica 8, 21000 Novi Sad, Serbia

\section{a Mail Address}

Corresponding author e-mail address Dragan Zikic

University of Novi Sad, Faculty of Agriculture, Dositeja Obradovica 8, 21000 Novi Sad

Serbia

Tel: $\quad(+381) 63559172$

Email: zikic@polj.uns.ac.rs

\section{EKeywords}

Behavior; broiler; dermatitis; footpad; litter

\section{ABSTRACT}

This study was conducted to evaluate the impact of litter type and litter treatment with enzymatic-bacterial production incidence and severity of footpad dermatitis and consequently on behavior of broiler chickens. A total of 1,200 one day-old Ross 308 broilers were randomly allocated to 4 treatments with 4 replicates in $2 \times 2$ factorial design. The first factor was the physical form of the straw (chopped on approximately $2 \mathrm{~cm}$ or un-chopped) and the second factor was addition of enzymaticbacterial product applied directly on the straw. Each replicate consisted of 75 as-hatched birds per pen. Occurrence and severity of the footpad dermatitis and histological evaluation of the scores was done at the end of the trial ( 42 days of age). During the trial, at 3 and 6 weeks of age, broiler behavior was observed by Scan Sampling Method. The results showed that chopped straw significantly lowered the incidence of footpad dermatitis. Chopped straw in combination with enzymaticbacterial product showed the lowest footpad dermatitis score in broilers. Histological procedures confirmed the macroscopic evaluation of the footpad dermatitis severity. The chopped straw had a significant effect on some behavioral patterns of broiler chickens. Differences were observed for dust bathing and scratching. Correlation between footpad dermatitis and birds locomotor activity was not confirmed.

\section{INTRODUCTION}

One of the most important factors in broiler production is the litter quality. Litter plays several very important roles such as moisture absorption, thermal insulation and allows bird-scratching (Grimes et al., 2002; Bilgili et al., 2009; Shepherd et al., 2010). It affects general health status, productive parameters, carcass quality, and welfare of broilers (Eichner et al., 2007; Bilgili et al., 2009; Garcês et al., 2013). Animal welfare audits in Europe often use foot, hock and breast burns lesions as an indicator of housing conditions and general welfare of the birds (Haslam et al., 2006). In fact, the footpad condition is an important aspect of poultry welfare that in severe cases can cause pain (Berg, 2004) resulting in unsteady walk (Hester et al., 1997) and reduced weight gain due to pain-induced decreases in feed intake (Martland, 1984; Martland, 1985).

A wide range of materials could be used as broiler litter: rice hulls, ground corncobs, stump chips, pine sawdust, white wood shavings, bark and chips, pine bark, clay sand, coconut husk, Guinea grass, newspaper, corn cob, wheat straw, ground rapeseed straw and silage maize (Grimes et al., 2002; Sirri et al., 2007; Meluzzi et al., 2008; Garcês et al., 2013). Each of these materials has advantages and disadvantages, but different particle size of these materials was seen to be one of the most important factors and has been examined as a contributing factor in the development of footpad dermatitis (FPD) (Shepherd et al., 2010). 
Zikic D, Djukic-Stojcic M, Bjedov S, Peric L, Stojanovic S, Uscebrka G
Effect of Litter on Development and Severity of FootPad Dermatitis and Behavior of Broiler Chickens
Various litter amendments such as chemicals - aluminum sulfate (Madrid et al., 2012), sodium bisulfate (Nagaraj et al., 2007; Li et al., 2012), zeolite (Li etal., 2008), microbiological preparation (IwaczukCzernik et al., 2007), or a commercial ammonia binding agent (Lazarevic et al., 2014) are used to reduce litter moisture, $\mathrm{pH}$ and $\mathrm{NH}_{3}$ emission in broiler houses. Some authors documented that such litter treatments might have positive effects on the occurrence of FPD (Nagaraj et al., 2007). Since the FPD is recognized as a welfare problem of broilers, a scoring method, that is fully validated histologically, is required in order to accurately define lesions and to establish a clear link between the macroscopic appearance of the lesion and its putative impact on chicken welfare (Michel et al., 2012).

The purpose of this study was to evaluate the influence of litter on the occurrence and severity of FPD in broiler chickens by valid histological methods of scoring and to examine the influence of bedding material on behavior and locomotor activity of broiler chicks.

\section{MATERIAL AND METHODS}

\section{Animals and experimental design}

The experiment was conducted at the Experimental farm of Faculty of Agriculture in Novi Sad. A total of 1,200 as-hatched one day-old Ross 308 broilers were randomly allocated to 4 treatments with 4 replicates in $2 \times 2$ factorial design. Each replicate consisted of a floor pen with 75 birds with $2.5 \mathrm{~kg}$ of straw per floor 1 $\mathrm{m}^{2}$. The first factor was the form of wheat straw used for the bedding - chopped (C) or un-chopped (U). The straw chopping was performed mechanically, and the length of the cut was about $20 \mathrm{~mm}$. The second factor was the litter treatment with enzymatic-bacterial product (Micropan ${ }^{\circledR}$ Simplex, Eurovix USA) in powder form which was applied on both chopped (CMP) and un-chopped straw (UMP). Micropan product (MP) contains active microorganisms and enzymes for the deodorization and sanification of poultry bedding and manure. Micropan was applied to the surface of the litter at the rate of $1 \mathrm{~kg} / 100 \mathrm{~m}^{2}$. It was applied three times during the production cycle - at the days 1, 15 and 35.

Broilers were reared to 42 days of age on a 3-phase commercial feeding program consisting of starter (121 days), grower (22-35 d) and finisher (36-42 d) diets. The composition of the basal diet is shown in Table 1.
Table 1 - Composition of experimental diets

\begin{tabular}{lccc}
\hline & $\begin{array}{c}\text { Starter } \\
(0-21 \mathrm{~d})\end{array}$ & $\begin{array}{c}\text { Grower } \\
(22-35 \mathrm{~d})\end{array}$ & $\begin{array}{c}\text { Finisher } \\
(36-42 \mathrm{~d})\end{array}$ \\
\hline Diet composition (g/kg) & & & \\
Corn & 488.3 & 526.1 & 578.4 \\
\hline Full fat soybean & 169.9 & 228.0 & 220.3 \\
Soybean meal (44\% CP) & 199.3 & 122.5 & 5.97 \\
\hline Wheat feed flour & 90.0 & 49.9 & 40.7 \\
Sunflower meal (33\% CP) & 0.00 & 30.0 & 60.0 \\
\hline Monocalcium phosphate & 11.8 & 10.3 & 9.40 \\
Limestone & 15.9 & 12.6 & 12.0 \\
\hline Salt & 2.1 & 2.7 & 2.7 \\
\hline Sodium bicarbonate & 1.8 & 8.0 & 7.0 \\
\hline L-Treonine & 1.2 & 0.20 & - \\
\hline L-Lysine HCl & 3.7 & 2.0 & 1.8 \\
\hline DL-methionine & 4.0 & 2.9 & 2.3 \\
Captex & 2.0 & 2.0 & 2.0 \\
\hline Vitamin and mineral premix & 10 & 10 & 10 \\
Calculated nutrient composition* & & & \\
\hline AME (MJ/kg) & 12.65 & 13.20 & 13.40 \\
\hline Crude protein (g/kg) & 220.0 & 210.0 & 190.0 \\
\hline Lysine (g/kg) & 14.3 & 12.4 & 10.9 \\
\hline Methionine (g/kg) & 7.2 & 6.1 & 5.7 \\
\hline Ca (g/kg) & 10.5 & 9.0 & 8.5 \\
\hline p total (g/kg) & 8.2 & 7.5 & 7.1 \\
\hline p available (g/kg) & 5.0 & 4.5 & 4.2 \\
\hline CPcrde & & & \\
\hline
\end{tabular}

CP-crude protein; Captex - mycotoxin binder, AME - apparent metabolizable energy ${ }^{*}$ According nutrition requirements for ROSS 308 (http://en.aviagen.com/)

Feed and water were available ad libitum. Birds were vaccinated against Newcastle disease (NCD) and infectious bursal disease (IBD) as required.

All procedures were conducted according to ethical norms proposed by the European Convention for the Protection of Vertebrate Animals Used for Experimental and Other Scientific Purposes, confirmed by Serbian authorities.

\section{Evaluation of footpad lesions}

The incidence and severity of FPD were measured at 42 days of age using the scoring method described by Eichner (2007): no lesions (score 0), lesions cover less than $25 \%$ of the footpad (score 1), lesions in wide areas, covering between $25 \%$ and $50 \%$ of the footpad (score 2), more than $50 \%$ lesion on the footpads (score 3) (Figure 1). The scoring was done by two independent observers on all birds from the trial. The evaluation was performed on both foots. The average score was used for statistical analyses. 


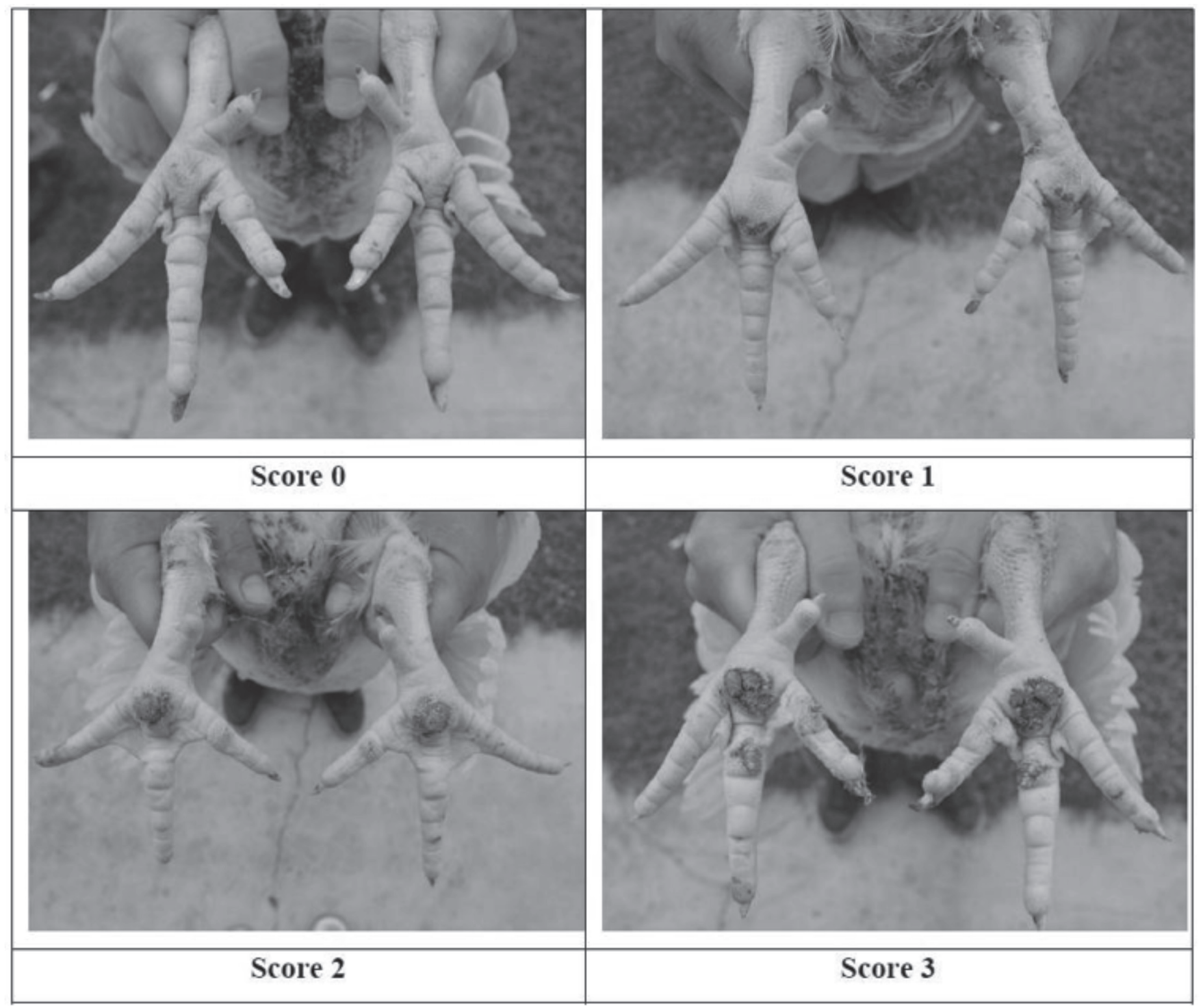

Figure 1 - Macroscopic evaluation of the footpad lesions

\section{Histological procedures}

The chicken's feet were sampled in the slaughterhouse. Random samples were taken from the birds representing each score from 0 to 3 . Five birds per each score were randomly sampled and 5 feet were taken for analyses. Feet were placed in $10 \%$ buffered formalin. The histological analyses were performed at the Faculty of Agriculture in Novi Sad. Each foot was cut from the epidermis of the footpad cushion and embedded in paraffin wax. Sections ( $5 \mu \mathrm{m}$ thick) were obtained for each sample and stained with haematoxylin and eosin. Histology parameters were determined using light microscope and pictures were taken with digital camera Leica DF-350.

\section{Behavioural observations}

At 3, and 6 weeks of age, a scan sampling method at the pen floor level was used for behavioral data. In scan sampling method the behavior of all the individuals in a group of animals are recorded at predetermined time intervals (Martin, 2007). Observations were made in the period from 10 AM to 2 PM over 1 day of each week by eight observers. Each pen floor was scanned every 20 minutes.

The following behavioral parameters were measured: resting (birds resting and not performing any other activities), walking (moving), feeding (at the feeder with head into the lip of the feeder), drinking (standing with head directly under the drinker line), dust bathing (bird forced the litter into the plumage by squatting on the 
ground and making appropriate movements with the body, wings and legs and scratching (bird moved the litter backwards with its feet). The frequency of each behavior in broilers was expressed as the percentage rate of daily collected data.

\section{Statistical analyses}

Data were analyzed by factorial ANOVA using the GLM procedure. Means were separated by Dunnett's post hoc test using StatSoft computer package (STATISTICA 11, 2012).

\section{RESULTS}

The footpad evaluation was performed at the end of the trial (42 days) and the incidence and severity of footpad lesions are presented in Table 2.

Table 2 - Effect of the litter treatment on the incidence of foot pad dermatitis (FPD) in broilers at 6 weeks of age

\begin{tabular}{|c|c|c|c|c|c|c|c|c|c|c|c|}
\hline \multirow{3}{*}{ Score } & \multicolumn{8}{|c|}{ Treatments } & \multicolumn{3}{|c|}{$p$ value of the main effects } \\
\hline & \multicolumn{2}{|c|}{$\begin{array}{l}\text { Un-chopped } \\
(U)\end{array}$} & \multicolumn{2}{|c|}{$\begin{array}{l}\text { Un-chopped with } \\
\text { MP(UMP) }\end{array}$} & \multicolumn{2}{|c|}{$\begin{array}{l}\text { Chopped } \\
\text { (C) }\end{array}$} & \multicolumn{2}{|c|}{$\begin{array}{c}\text { Chopped with MP } \\
\text { (CMP) }\end{array}$} & \multirow{7}{*}{ 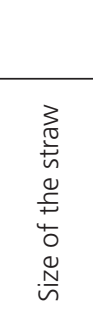 } & \multirow{7}{*}{ 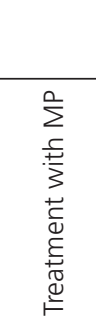 } & \multirow{7}{*}{ 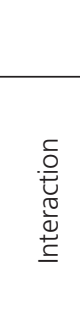 } \\
\hline & No. & $\%$ & No. & $\%$ & No. & $\%$ & No. & $\%$ & & & \\
\hline 0 & 5 & 2.69 & 3 & 1.48 & 3 & 1.50 & 26 & 14.44 & & & \\
\hline 1 & 57 & 30.65 & 86 & 42.36 & 65 & 32.50 & 77 & 42.78 & & & \\
\hline 2 & 57 & 30.65 & 70 & 34.48 & 66 & 33.00 & 47 & 26.11 & & & \\
\hline 3 & 67 & 36.02 & 44 & 21.67 & 66 & 33.00 & 30 & 16.67 & & & \\
\hline Total & 186 & 100.00 & 203 & 100.00 & 200 & 100.00 & 180 & 100.00 & & & \\
\hline Average & \multicolumn{2}{|c|}{$1.94^{c}$} & \multicolumn{2}{|c|}{$1.76^{b}$} & \multicolumn{2}{|c|}{$1.71^{\mathrm{b}}$} & \multicolumn{2}{|c|}{$1.47^{\mathrm{a}}$} & 0.000 & 0.000 & 0.530 \\
\hline
\end{tabular}

a-cMeans within the same row with different superscript differs significantly $(p<0.05)$

$\mathrm{MP}$ - micropan product

Results indicate that the inclusion of MP treatment in both chopped and un-chopped straw severity of food pad lesions decreased and the average score was lower. That means higher incidence of score 1 lesions in MP groups and lower incidence of scores 2 and 3. It is true that phase 1 will probably progress to the scores 2 or 3 in the future, but at the age of 6 weeks birds form MP untreated groups have already developed scores 2 and 3. Upon that we based our statement that MP treatment reduces the severity of FPD in broilers.

Physical form of the straw as well as the application of enzymatic-bacterial product (MP) had a statistically significant effect on incidence of FPD $(p<0.01)$. Reducing the size of the straw on approximately $2 \mathrm{~cm}$ showed decreased significantly occurrence of FPD in broilers. The similar effect was established with the addition of MP $(p<0.01)$. When comparing all four treatments the smallest average score (1.47) was found in the group CMP (chopped straw with MP) and the highest average score (1.94) was established in group raised on un-chopped non-treated straw $(U)$.

Analysis of the severity of foot pad lesions showed that the highest number of birds with no lesions (score 0 ) was found in the group CMP (chopped straw with $\mathrm{MP}$ ) and the number of birds with the worst score representing the deep epithelial lesions of foot pad (score 3) was in groups without MP treatment of straw ( $U-67$ birds and C-66 birds).
Results of the histological analyses of footpads with different severity of FPD are illustrated on the Figure 2. Footpad without damage (score 0, Figure 2A) has a normal skin structure with no pathological changes. There is a clear division of keratin layer, epidermis and dermis and all layers are of normal thickness. On Figure 2B (score 1) mild changes of the footpad skin can be noticed. This is the first phase in development of footpad dermatitis. Scales are prominent, enlarged with mild epidermal hyperplasia and hyperkeratosis. Dermal superficial congestion edema and mild perivascular infiltrates were present on some sections. Histological changes of FPD score 2 (Figure 2C) are characterized by moderate to marked hyperplasia and hyperkeratosis of the epidermis, abundant heterophilic epidermal exocytosis with pustule formation and congestion in the superficial dermis with inflammatory infiltration. The most severe FPD is scored by 3 and that means that more than $50 \%$ of the foot is covered with lesions. On the histological sections (Figure 2D) ulceration (fullthickness necrosis of the epidermis, replaced by a necrotic and suppurative material) and underlying granulation tissue could be seen.

Obtained results clearly indicate a strong correlation between macroscopic and microscopic evaluation of FPD. 
Zikic D, Djukic-Stojcic M, Bjedov S, Peric L, Stojanovic S, Uscebrka G

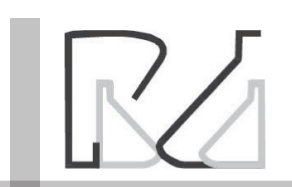

Effect of Litter on Development and Severity of FootPad Dermatitis and Behavior of Broiler Chickens

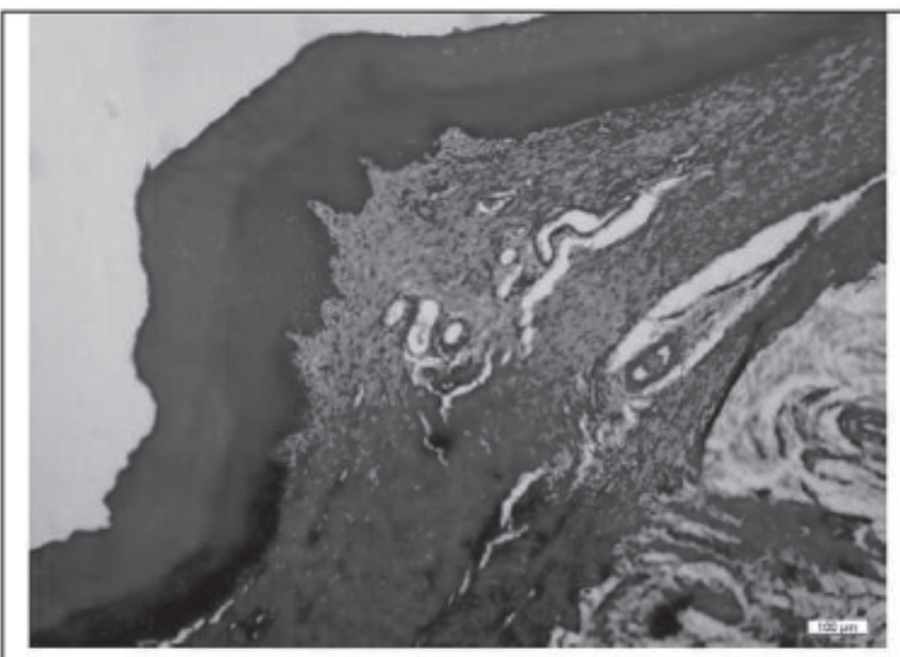

A

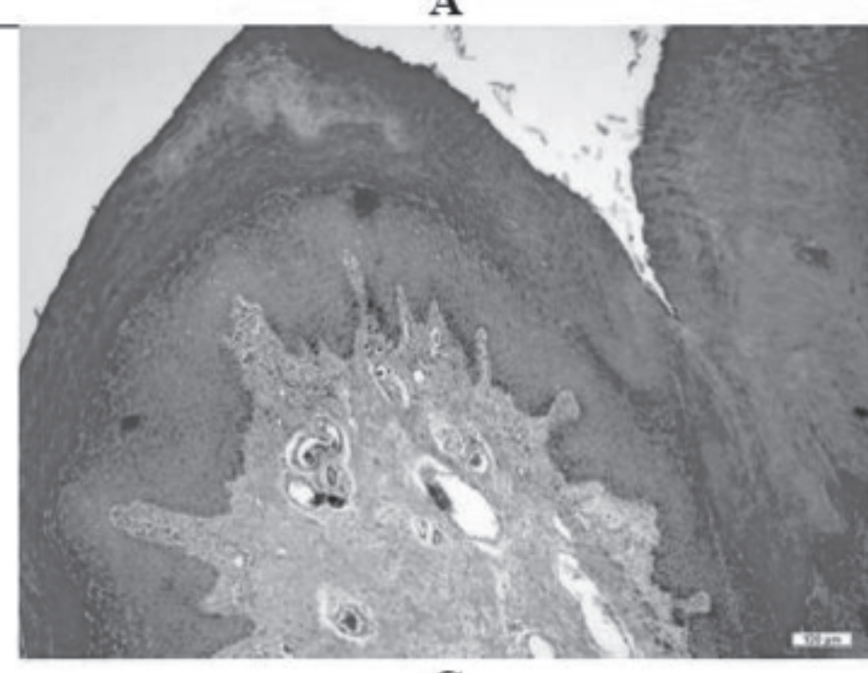

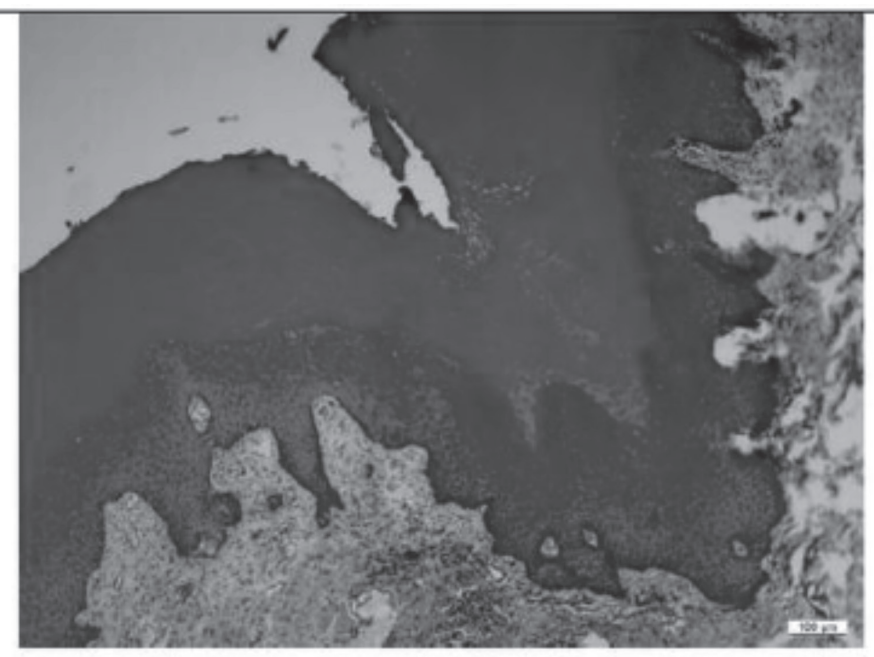

B

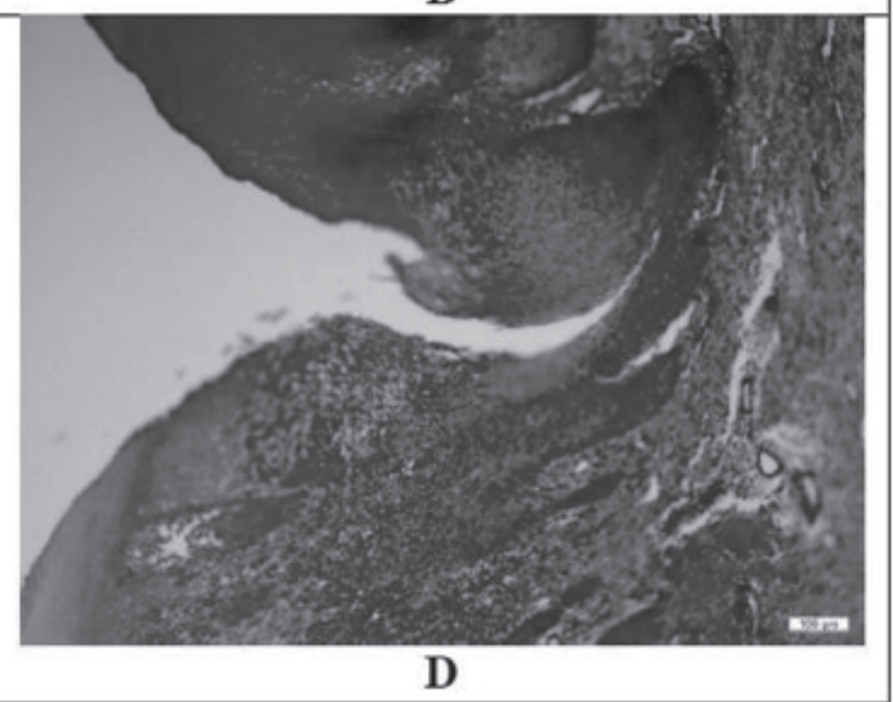

Figure 2 - Histological characteristics of different footpad lesion types A) no lesions, B) lesions -score 1, C) lesions - score 2, D) lesions - score 3 (H\&E, UV 100x)

The results presented in Table 3 show that the broilers reared on chopped straw spent significantly more time in feeding and had significantly higher scratching activity in the $3^{\text {rd }}$ week of age. However, no

Table 3 - Behavior of birds at 3 and 6 weeks of age

\begin{tabular}{|c|c|c|c|c|c|c|c|}
\hline Week & Treatment & Resting (\%) & Moving (\%) & Feed intake (\%) & Water intake $(\%)$ & Dust bathing (\%) & Scratching (\%) \\
\hline \multirow{4}{*}{3} & Chopped (C) & 65.64 & 4.3 & $3.66^{b}$ & 5 & 2.05 & $5.40^{\mathrm{a}}$ \\
\hline & Un-chopped (U) & 59.83 & 4.09 & $7.58^{\mathrm{a}}$ & 5.75 & 1.26 & $1.80^{\mathrm{b}}$ \\
\hline & Chopped with MP (CMP) & 61.47 & 3.9 & 5.2 & 3.34 & 2.95 & 3.4 \\
\hline & Un-chopped with MP (UMP) & 61.31 & 4.37 & 6.62 & 3.91 & 2.06 & 3 \\
\hline \multirow{2}{*}{ p value } & Litter & 0.923 & 0.560 & $0.028 *$ & 0.967 & 0.089 & $0.001 * *$ \\
\hline & MP & 0.887 & 0.823 & 0.543 & 0.089 & 0.765 & 0.987 \\
\hline \multirow{4}{*}{6} & Chopped (C) & 79.32 & 3.58 & 4.01 & 5.2 & $3.1^{\mathrm{a}}$ & 1.1 \\
\hline & Un-chopped (U) & 79.94 & 3.61 & 4.65 & 6.2 & $0.4^{b}$ & 0.8 \\
\hline & Chopped with MP (CMP) & 72.62 & 3.42 & 6.22 & 8.6 & 1.2 & 1.3 \\
\hline & Un-chopped with MP (UMP) & 75.6 & 2.35 & 5.89 & 7.4 & 1.6 & 0.9 \\
\hline \multirow{2}{*}{ p value } & Litter & 0.856 & 0.382 & 0.693 & 0.658 & $0.001 * *$ & 0.487 \\
\hline & MP & 0.231 & 0.830 & 0.324 & 0.255 & 0.589 & 0.523 \\
\hline
\end{tabular}

a-b Means with different superscript in the same column within the same age differs significantly $(p<0.05)$

${ }^{*}$ Statistically significant effect of the factor $(p<0.05) * *(p<0.01)$

MP - micropan product 
Zikic D, Djukic-Stojcic M, Bjedov S, Peric L, Stojanovic S, Uscebrka G
Effect of Litter on Development and Severity of FootPad Dermatitis and Behavior of Broiler Chickens difference was found in resting, walking, drinking and dust bathing between birds reared on chopped and un-chopped straw $(p>0.05)$. At the $6^{\text {th }}$ week of age the most remarkable differences were obtained for dust bathing. Only for this parameter, we documented statistically significant difference $(p<0.05)$ between groups of broilers reared on chopped and un-chopped straw. Addition of MP did not lead to significant differences in broiler's behavior reared on chopped and un-chopped straw at both moments of observation.

\section{DISCUSSION}

There are many studies which pointed out a clear connection between litter type and incidence of FPD in broilers (Berg, 2004; Bilgili et al., 2009; Shepherd et al., 2010). In the present study, chickens reared on chopped straw showed lower rates of FPD occurrence compared to broilers raised on un-chopped straw probably because of the better condition of the litter and lower ammonia emission. This assumption is in line with findings that long straw had higher ammonia emission compared to chopped straw (SlobodzianKsenicz et al., 2002). There was a strong tendency at long straw litter for caking with eventually close to 100 $\%$ of flooring being covered by almost impermeable layer. It was suggested that long straw should be particularly avoided for negative environmental impact in broiler housing (Slobodzian-Ksenicz \& Kuczyński, 2002). There are results confirming that particle size of litter material has an important role in the development of FPD (Bilgili et al., 2009; Shepherd et al., 2010). The highest incidence of FPD was found with the coarse particle board treatment (Hester et al., 1997).

The addition of enzymatic-bacterial product (MP) significantly lowered the incidence of FPD. Crust formation at the surface of the litter treated with MP was observed from the $4^{\text {th }}$ to the $6^{\text {th }}$ week of the trial. The formed crust was dry, thus the footpads were cleaner and it was assumed that this was a reason for lower FPD with chickens reared on un-chopped straw. Litter amendments are often used in poultry production to reduce litter $\mathrm{pH}$ to control ammonia and as an intervention method in houses with a recurring disease issue such as gangrenous dermatitis (Shepherd et al., 2010). Results of other authors showed that litter treatments with chemical or microbiological products have positive effects on litter condition by lowering $\mathrm{pH}$ value (Madrid et al., 2012), reducing ammonia emission (Kim \& Patterson, 2003; Iwaczuk-Czernik et al., 2007; Li et al., 2008; Madrid et al., 2012), or litter moisture (Iwaczuk-Czernik et al., 2007; Lazarevic et al., 2014). Such litter treatments might have a positive (decreasing) effect on FPD occurrence (Purswell et al., 2013). Alum-treated litter had no detrimental effect on the development of footpad and hock burns (Madrid et al., 2012) while other authors (Nagaraj et al., 2007) stated there was a trend of decreasing incidence and FPD severity when $\mathrm{NaHSO}_{4}$ was used.

Histological analyses of footpad lesions were performed in order to establish connection between macroscopic and microscopic features of the four grades of footpad lesions. The samples of each lesion type corresponded to a typical macroscopic appearance and shared the same histological features. Together with the increase of the surface of footpad which is affected with lesions, there is an increase of the depth of the affected skin layers. The described microscopic lesions in this study were very close to those described by other authors (Martland, 1984; Greene et al., 1985; Martland, 1985; Michel et al., 2012). The results showed that applied scoring method (scoring from 0-3) could be applied in monitoring of FPD in welfaremonitoring programs. Histological analyses indicated the presence of the severe damage of the deeper layers of the skin which could cause a strong pain in birds with higher FPD score. From that reason the behavior of the broilers was observed at 3 and 6 weeks of age.

In both weeks, for all observed groups, walking was below $5 \%$ of the total daily time budget, which coincides with the results of other authors (Bizeray et al., 2000; Weeks et al., 2000; Cornetto \& Estevez, 2001; Reiter \& Kutritz, 2001; Bokkers, 2004; Djukic, 2006; Jordan et al., 2011). The appearance of the lesions did not affect the decrease in the activity of broilers. Other observed parameters, such as resting, feeding, drinking, dust bathing, and scratching are in accordance with results from other similar studies (Reiter \& Kutritz, 2001; Bokkers, 2004; Djukic, 2006; Jordan et al., 2011).

For feeding, dust bathing and scratching, differences between chopped and un-chopped straw were statistically significant. The drinking, feeding, dust bathing and scratching are significantly different between the different materials (sawdust, sand, rice husks and recycled paper) (Toghyani et al., 2010; Villagrá et al., 2014). If given a choice, chickens prefer to spend more time on the loosest litter - sand and dust bathe (Arnould et al., 2004; Toghyani et al., 2010; Villagrá et al., 2014). On the other hand, other researchers showed that broilers behavior did not differ between chickens reared on different types of 
Zikic D, Djukic-Stojcic M, Bjedov S, Peric L, Stojanovic S, Uscebrka G

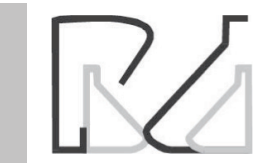

Effect of Litter on Development and Severity of FootPad Dermatitis and Behavior of Broiler Chickens litter (El-Laithy, 2003; Karousa et al., 2012). The choice of material for the litter can also be an effective way to increase activity of broiler chickens (Shields et al., 2005). Chickens reared on chopped straw, without the addition of MP showed significantly more dust bathe and scratch. The reason was loose litter. Addition of MP led to the formation of crust on the surface of the litter. Therefore, surface was not friable and chickens showed less scratching and dust bathing.

\section{CONCLUSIONS}

The present study has produced evidence that the size of the straw has a significant effect on occurrence of FPD. The shorter fibers of chopped straw significantly lowered the incidence of FPD. Chopped straw in combination with MP showed the lowest score of FPD in broilers. Histological procedures validated and confirmed the macroscopic evaluation of the FPD severity. A strong positive correlation was found between macroscopic and microscopic evaluation of FPD. The chopped straw had a significant effect on some behavior patterns of broiler chickens. Differences were found for dust bathing and scratching. Correlation between footpad dermatitis and locomotor activity of the birds was not confirmed. Chopped straw is more suitable material for a litter compared to un-chopped, because it facilitates birds to express a more comfort behavior and thereby improve their welfare state.

\section{ACKNOWLEDGEMENTS}

This work has been funded by the Ministry of Education, Science and Technology Development Republic of Serbia as a part of the Project No. TR 31033

\section{REFERENCES}

Arnould C, Bizeray D, Faure JM, Leterrier C. Effects of the addition of sand and string to pens on use of space, activity, tarsal angulations and bone composition in broiler chickens. Animal Welfare 2004;13:87-94.

Berg C. Pododermatitis and hock burn in broiler chickens. In: Weeks CA, Butterworth A, editors. Measuring and auditing broiler welfare. Wallingford: CABI Publishing; 2004. p.37-49.

Bilgili SF, Alley MA, Hess JB, Blake JP, Macklin KS, Sibley JL. Influence of bedding material on footpad dermatitis in broiler chickens. Journal of Applied Poultry Research 2009;18:583-589.

Bizeray D, Leterrier C, Constantin P, Picard M, Faure JM. Early locomotor behaviour in genetic stocks of chickens with different growth rates. Applied Animal Behaviour Science 2000;68:231-242.

Bokkers E. Behavioural motivations and abilities in broilers [Sissertation]. Wageningen (NL): Wageningen University; 2004.
Cornetto T, Estevez I. Influence of vertical panels on use of space by domestic fowl. Applied Animal Behavior Science 2001;71:141-153.

Djukic M. Die bedeutung der laufaktivität und der gewichtsentwicklung bei der entstehung von beinschaden beim mastgeflügel [dissertation]. Hohenheim (DE): University of Hohenheim; 2006.

Eichner G, Vieira SL, Torres CA, Coneglian JLB, Freitas DM, Oyarzabal OA Litter moisture and foot pad dermatitis as affected by diets formulated on an all-vegetable basis or having the inclusion of poultry by-product. Journal of Applied Poultry Research 2007;16:344-350.

El-Laithy SMM. Effect of some managerial factors on turkey performance and behaviour [dissertation]. Zagazig (LE): Zagazig University; 2003.

Garcês A, Afonso SMS, Chilundo A, Jairoce CTS. Evaluation of different litter materials for broiler production in a hot and humid environment:1. Litter characteristics and quality. Journal of Applied Poultry Research 2013:22:168-176

Greene JA, McCracken RM, Evans RT. A contact dermatitis of broilers Clinical and pathological findings. Avian Pathology 1985;14:23-38.

Grimes JL, Smith J, Williams CM. Some alternative litter materials used for growing broilers and turkeys. World's Poultry Science Journal 2002;58:515-526

Haslam SM, Brown SN, Wilkins LJ, Kestin SC, Warriss PD, Nicol CJ. Preliminary study to examine the utility of using foot burn or hock burn to assess aspects of housing conditions for broiler chicken. British Poultry Science 2006;47:13-18.

Hester PY, Cassens DL, Bryan TA.The applicability of particleboard residue as a litter material for male turkeys. Poultry Science 1997;76:248-255.

Iwaczuk-Czernik K, Witkowska D, Sowinska J, Wójcik A, Mituniewicz T. The effect of a microbiological and a disinfecting preparation on the physical and chemical properties of litter and the results of broiler chicken breeding. Polish Journal of Natural Science 2007;22:395-406.

Jordan D, Štuhec I, Besseik W. Effect of whole wheat and feed pellets distribution in the litter on broilers' activity and performance. Archiv für Geflügelkunde 2011;75:98-103.

Karousa MMA, Meneeh ISB, Ahmed SAA, Ahmed EAA, Youseif HAA. Effect of litter materials on broiler behaviour and performance. Benha Veterinary Medical Journal 2012;23:142-149.

Kim WK, Patterson PH. Effect of minerals on activity of microbial uricase to reduce ammonia volatilization in poultry manure. Poultry Science 2003:82:223-231

Lazarevic M, Resanovic R, Vucicevic I, Kocher A, Moran CA. Effect of feeding a commercial ammonia binding product De-Odorase ${ }^{\mathrm{TM}}$ on broiler chicken performance. Journal of Applied Animal Nutrition 2014;2:1-6.

Li H, Lin C, Collier S, White-Hansen S, Brown W. Assessment of repeated litter amendment application on ammonia reduction [paper 121337336]. Proceedings of the ASABE Annual International Meeting; 2012 Jul 29-Aug 1; Dallas. Texas; 2012

Li H, Xin H, Burns RT, Liang Y. Reduction of ammonia emissions from stored laying hen manure through topical application of zeolite, $\mathrm{Al}+\mathrm{Clear}$, Ferix-3, or poultry litter treatment. Journal of Applied Poultry Research $2008 ; 17: 421-431$

Madrid J, López MJ, Orengo J, Martínez S, Valverde M, Megías MD, et al. Effect of aluminum sulfate on litter composition and ammonia emission in a single flock of broilers up to 42 days of age. Animal 2012;6:13221329 . 
Zikic D, Djukic-Stojcic M, Bjedov S, Peric L, Stojanovic S, Uscebrka G

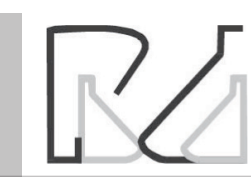

Effect of Litter on Development and Severity of FootPad Dermatitis and Behavior of Broiler Chickens
Martin P, Bateson P. Measuring behaviour. Cambridge: Cambridge University Press; 2007.

Martland MF. Wet litter as a cause of plantar pododermatitis, leading to foot ulceration and lameness in fattening turkeys. Avian Pathology $1984 ; 13: 241-252$

Martland MF. Ulcerative dermatitis in broiler chickens: The effects of wet litter. Avian Pathology 1985;14:353-364.

Meluzzi A, Fabbri C, Folegatti E, Sirri F. Survey of chicken rearing conditions in Italy:Effects of litter quality and stocking density on productivity, foot dermatitis and carcase injuries. British Poultry Science 2008;49:257264.

Michel V, Prampart E, Mirabito L, Allain V, Arnould C, Huonnic D, et al. Histologically-validated footpad dermatitis scoring system for use in chicken processing plants. British Poultry Science 2012;53:275-281.

Nagaraj M, Wilson CAP, Saenmahayak B, Hess JB, Bilgili SF. Efficacy of a litter amendment to reduce pododermatitis in broiler chickens. Journal of Applied Poultry Research 2007;16:255-261.

Purswell JL, Davis JD, Kiss AS, Coufal CD. Effects of frequency of multiple applications of litter amendment on litter ammonia and live performance in shared airspace. Journal of Applied Poultry Research 2013:22:469-473

Reiter K, Kutritz B. Verhalten und beinschwächen von broilern verschiedener herkünfte. Archiv für Geflügelkunde 2001;65:1-5.
Shepherd EM, Fairchild BD. Footpad dermatitis in poultry. Poultry Science 2010;89:2043-2051.

Shields SJ, Garner JP, Mench JA. Effect of sand and wood-shavings bedding on the behavior of broiler chickens. Poultry Science 2005;84:18161824

Sirri F, Minelli G, Folegatti E, Lolli S, Meluzzi A. Foot dermatitis and productive traits in broiler chickens kept with different stocking densities, litter types and light regimen. Italian Journal of Animal Science 2007;6:734736 .

Slobodzian-Ksenicz O, Kuczyński T. Effect of Litter Type on Ammonia Emission in Turkey Housing. Agricultural Engineering International: the CIGR Journal 2002;4:1-11.

Toghyani M, Gheisari A, Modaresi M, Ali Tabeidian S, Toghyani M. Effect of different litter material on performance and behaviour of broiler chickens. Applied Animal Behaviour Science 2010;122:48-52.

Villagrá A, Olivas I, Althaus RL, Gómez EA, Lainez M, Torres AG. Behavior of broiler chickens in four different substrates:a choice test. Brazilian Journal of Poultry Science 2014;16:67-76.

Weeks CA, Danbury TD, Davies HC, Hunt P, Kestin SC. The behaviour of chickens and its modification by lameness. Applied Animal Behaviour Science 2000;67:111-125. 